\title{
In vitro adenovirus mediated gene transfer to the human cornea
}

\author{
C F Jessup, H M Brereton, D J Coster, K A Williams
}

Br J Ophthalmol 2005;89:658-661. doi: 10.1136/bjo.2004.061754

Background/aims: Replication deficient adenovirus is an efficient vector for gene transfer to the cornea. The aim was to optimise the transduction of human corneal endothelium with adenoviral vectors and to measure transgene production from transduced corneas.

Methods: Adenoviral vectors (AdV) encoding enhanced green fluorescent protein (eGFP) or a transgenic protein (scFv) were used to transfect 34 human corneas. Reporter gene expression was assessed after 72-96 hours of organ culture. The kinetics of scFv production was monitored in vitro for 1 month by flow cytometric analysis of corneal supernatants.

Results: Transduction of human corneas with high doses $\left(5 \times 10^{7}-3 \times 10^{8} \mathrm{pfu}\right)$ of AdV caused eGFP expression in 12$100 \%$ of corneal endothelial cells. Corneas were efficiently transduced following up to 28 days in cold storage. Very high $\mathrm{AdV}$ doses $\left(2 \times 10^{9} \mathrm{pfu}\right)$ reduced endothelial cell densities to 98 (SD 129) nuclei/ $/ \mathrm{mm}^{2}$ (compared to 2114 (716) nuclei $/ \mathrm{mm}^{2}$ for all other groups). Transgenic protein production peaked at $2.4(0.9) \mu \mathrm{g} /$ cornea/day at 2 weeks post-transduction, and decreased to $1.2(0.4) \mu \mathrm{g} /$ cornea/ day by 33 days, at which time endothelial cell density had decreased to 431 (685) nuclei $/ \mathrm{mm}^{2}$.

Conclusion: Human corneas can be efficiently transduced by $\mathrm{AdV}$ following extended periods of cold storage, and transgene expression is maintained for at least 1 month in vitro.

C orneal allograft rejection is the major cause of human corneal graft failure. ${ }^{1}$ Gene transfer to corneal endothelium has been shown to modulate corneal allograft rejection in a number of experimental models, ${ }^{2-5}$ thereby providing proof of principle for future attempts to reduce the incidence of rejection in humans. The literature on gene therapy of the cornea has recently been reviewed..$^{6-8}$ Vector systems that have been used successfully to transduce reporter genes to human corneas include replication deficient adenovirus, ${ }^{9}$ lentivirus, ${ }^{10}$ activated polyamidoamine dendrimers, ${ }^{11}$ and synthetic peptides. ${ }^{12}$

Of the currently available vectors, adenovirus appears to be the most efficient at transducing corneal endothelial cells. We were keen to explore the efficacy of adenoviral vector transfer to the human cornea in more depth.

\section{MATERIALS AND METHODS}

\section{Human corneas}

Human corneas were collected by the Eye Bank of South Australia for clinical transplantation, with permission from the next of kin of recently dead people. Some donor families agreed that the corneas be used for research, should they be found to be unsuitable for transplantation. Thirty four human corneas were accordingly used in this study over a period of 28 months. No information other than the number of days that a cornea had been stored in the eye bank and the donor age was provided to the investigators. The use of corneas for research purposes was approved by the Flinders clinical research ethics committee.

\section{Adenoviral vectors}

A replication deficient E1, E3 deleted adenovirus (AdV) serotype 5 encoding enhanced green fluorescent protein (eGFP) under the transcriptional control of a CMV promoter (AdGFP) was the kind gift of Professor B Vogelstein (Johns Hopkins University, Baltimore, MD, USA). AdV encoding an anti-rat CD4 single chain antibody fragment $(\mathrm{scFV})^{13}$ with a mammalian secretory leader sequence on a CMV promoter and eGFP on a separate CMV promoter was constructed. The $\mathrm{scFV}$ transgene was chosen because it encodes a secreted model protein that is non-toxic and does not bind to the human cornea, although it will bind specifically to rat CD4 molecules. AdV was propagated in ElA, ElB trans-complementing 293 cells. AdV was purified from transduced 293 cell culture lysates over caesium chloride density gradients and titred by the tissue culture infectious dose method. ${ }^{14}$ Titres of different batches varied from $3 \times 10^{9}-5 \times 10^{10} \mathrm{pfu} / \mathrm{ml}$.

Transduction of human corneal endothelium with AdV Following enucleation, corneas were stored for 3-28 days at $4^{\circ} \mathrm{C}$ in Optisol-GS corneal storage medium (Bausch and Lomb, Rochester, NY, USA) before being made available for research. Corneas were transduced with $2 \times 10^{6}-2 \times 10^{9} \mathrm{pfu} /$ cornea AdV (estimated multiplicity of infection (MOI) 1010000 ) at room temperature for 2.5 hours in a total volume of $300 \mu \mathrm{l}$ in HEPES buffered RPMI medium (ICN Pharmaceuticals, Costa Mesa, CA, USA) supplemented with $2 \% \mathrm{v} / \mathrm{v}$ heat inactivated $\left(56^{\circ} \mathrm{C}, 30\right.$ minutes $)$, fetal calf serum (FCS) $100 \mathrm{IU} / \mathrm{ml}$ penicillin, $100 \mu \mathrm{g} / \mathrm{ml}$ streptomycin and 2 mM L-glutamine (all from Gibco BRL, Gaithersburg, MD, USA). Corneas were then cultured in $50 \mathrm{ml}$ HEPES buffered RPMI medium (as described above) supplemented with $10 \%$ FCS and $2.5 \mu \mathrm{g} / \mathrm{ml}$ amphotericin $\mathrm{B}$ and incubated at $37^{\circ} \mathrm{C}$ in $5 \% \mathrm{CO}_{2}$ in air.

\section{Assessment of transduction of human corneas with AdV}

To quantify the number of cells expressing eGFP, corneas were fixed in buffered formalin and counterstained with $300 \mu \mathrm{l}$ of $10 \mu \mathrm{g} / \mathrm{ml}$ Hoechst 33258 nuclear dye (Sigma Chemical Co, St Louis, MO, USA) for 30 minutes at room temperature. Corneas were dissected through the stroma and

Abbreviations: AdGFP, replication deficient E1, E3 deleted adenovirus serotype 5 encoding GFP; AdV, adenovirus based vector; eGFP, enhanced green fluorescent protein; FCS, fetal calf serum; MOI, multiplicity of infection; PBS, phosphate buffered saline; pfu, plaque forming units; scFv, single chain antibody fragment 

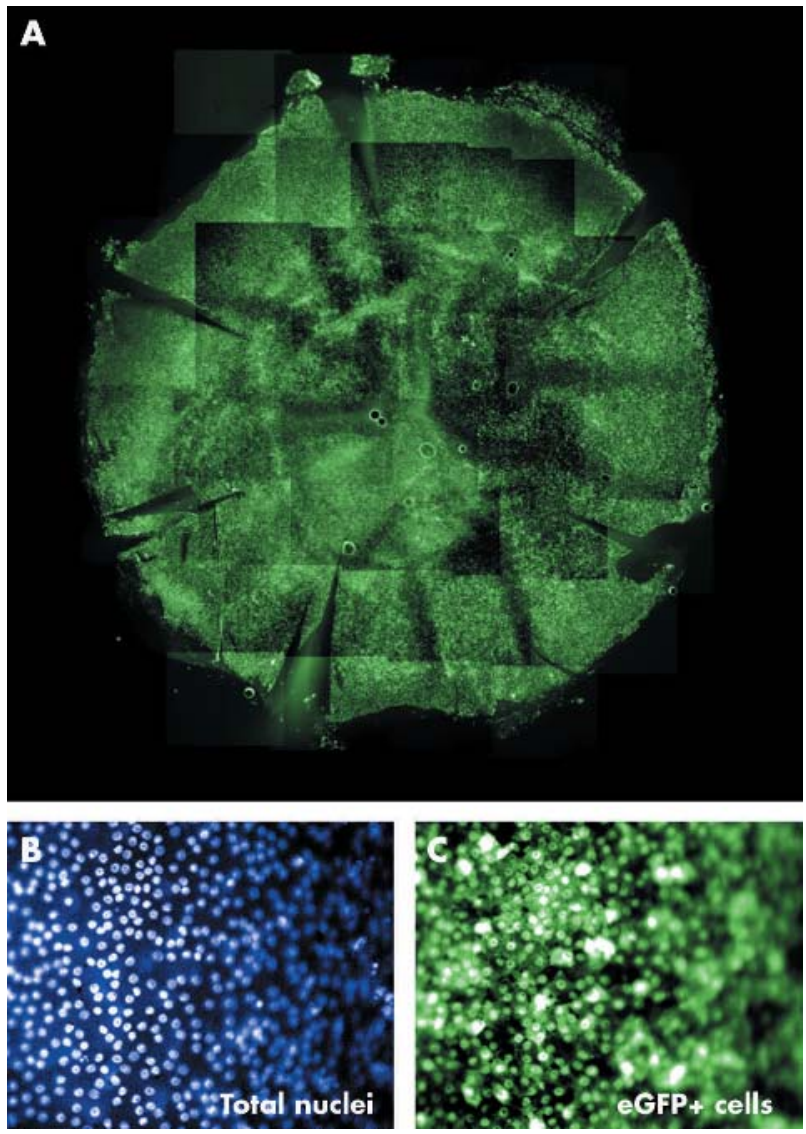

Figure 1 Reporter gene expression in AdV modified human corneal endothelium. (A) A human cornea transduced in vitro with $2 \times 10^{7}$ pfu AdV encoding eGFP. The image was captured at the fluorescence microscope and digitally collated. Hoechst 33258 stained corneal endothelial cell nuclei were detected under ultraviolet light (B) and eGFP positive cells in the same field were detected under blue light (C). Original magnification: $A: 4 \times ; B, C: 20 \times$.

the endothelium was mounted in buffered glycerol and examined at the fluorescence microscope. Five $0.15 \mathrm{~mm}^{2}$ central fields were examined for each cornea and the number of endothelial cell nuclei and eGFP positive cells recorded. Secreted transgenic anti-rat CD4 scFv was detected by flow cytometry on rat thymocytes, which are CD4 positive, as described in detail elsewhere. ${ }^{13}$ Briefly, thymocytes were incubated with $50 \mu \mathrm{l}$ corneal supernatants for 30 minutes at $4^{\circ} \mathrm{C}$, followed sequentially by anti-polyhistidine monoclonal antibody (Sigma), biotinylated anti-mouse antibody (DakoCytomation, Carpinteria, CA, USA) and streptavidinR-phycoerythrin conjugate (Molecular Probes, Eugene, OR, USA). Fluorescence was measured on a FACScan flow cytometer (Becton Dickinson, Franklin Lakes, NJ, USA). To calculate the amount of functionally active transgenic protein produced by an AdV transduced human cornea, serial dilutions of purified scFv (CSL Ltd, Melbourne, Victoria, Australia) were tested against rat thymocytes by flow cytometry and the data used to create a standard curve. $\mathrm{ScFv}$ concentrations in corneal supernatants were then estimated using the linear portion of the curve.

\section{Statistics}

Data from dosage groups were compared by one way ANOVA with Tukey-Kramer multiple comparisons post hoc tests, and relations were analysed by univariate linear regression and the Spearman rank correlation test.

\section{RESULTS}

Twenty nine corneas from donors with a mean age of 70 (SD 14 ) years were stored in standard eye bank conditions for a mean of 18 (7) days before being transduced with different doses of AdV. Following Hoechst 33258 staining and surgical removal of the epithelium, eGFP positive endothelial cells were detected in corneal flat mounts (fig l). The percentage of eGFP positive corneal endothelial cells is documented in table 1 . Two transduction failures $(<2 \%$ of endothelial cells expressing eGFP) were seen, one each in the low and high AdV dosage groups. The efficiency of transduction varied among individual corneas. The best efficiency of $78 \%(31 \%)$ was observed in the high dose group. There was no significant difference in transduction efficiency between groups treated with intermediate and high doses of AdV. Efficiency of transduction in these corneas did not correlate with donor age, endothelial cell density or time in storage before transduction $(\mathrm{p}>0.05)$.

Endothelial cell densities did not correlate with donor age or storage time before transduction $(\mathrm{p}>0.05)$ (data not shown). At 72-96 hours post-transduction, corneal endothelial cell

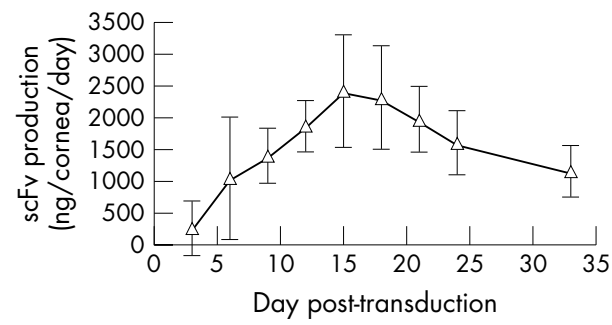

Figure 2 Production of transgenic protein by $\mathrm{AdV}$ modified human corneas. Human corneas $(n=5)$ were transduced with high doses of $A d V$ $\left(6 \times 10^{7}-3 \times 10^{8}\right.$ pfu per cornea) encoding a transgenic protein (scFv) and maintained in organ culture in vitro. Supernatants were sampled regularly and assayed for scFv levels by flow cytometry on rat thymocytes. Protein production rates were calculated as ng per cornea per day. Points represent mean (SD).

Table 1 Efficiency of transduction of human corneal endothelium by AdV encoding eGFP

\begin{tabular}{|c|c|c|c|c|c|c|c|}
\hline AdV dose (MOI)* & No & $\begin{array}{l}\text { pfu Adv per } \\
\text { cornea }\end{array}$ & $\begin{array}{l}\text { Donor aget } \\
\text { (years) }\end{array}$ & $\begin{array}{l}\text { Storage time†‡ } \\
\text { (days) }\end{array}$ & $\begin{array}{l}\text { Endothelial cell } \\
\text { density } ₫ \\
\left(\text { cells } / \mathrm{mm}^{2} \text { ) }\right.\end{array}$ & $\begin{array}{l}\% \text { eGFP+ cells } \\
\text { per cornea† } \S\end{array}$ & $\begin{array}{l}\text { Transduction } \\
\text { failures } 9\end{array}$ \\
\hline None & 3 & 0 & $71(6)$ & $21(7)$ & $1367(952)$ & 0 & - \\
\hline Low (10) & 3 & $2 \times 10^{6}$ & $72(4)$ & $25(3)$ & $2720(611)^{* *}$ & $8(3)$ & 1 \\
\hline Intermediate (25-100) & 8 & $5 \times 10^{6}-2 \times 10^{7}$ & $68(10)$ & $17(6)$ & $2195(558)^{\star *}$ & $54(31)$ & 0 \\
\hline High (250-1500) & 13 & $5 \times 10^{7}-3 \times 10^{8}$ & 72 (19) & $16(7)$ & $2163(669)^{* *}$ & 78 (31)†† & 1 \\
\hline Very high (10000) & 2 & $2 \times 10^{9}$ & $65(8)$ & $27(2)$ & 98 (129) & $64(26)$ & 0 \\
\hline
\end{tabular}

*MOI: multiplicity of infection; †Mean (SD); $\ddagger$ Time in cold storage from enucleation until transduction; $\S A$ s calculated from five central fields $\left(0.15\right.$ mm $\left.{ }^{2}\right)$ on corneal flat mounts by fluorescence microscopy; $\uparrow$ Transduction failures: fewer than $2 \%$ eGFP positive cells/cornea; ${ }^{* *} \mathrm{p}<0.01$ compared to very high dose group; $\dagger+\mathrm{p}<0.05$ compared to low and no dose groups. 
densities were not significantly different among untreated corneas or corneas treated with low, intermediate, or high doses of $\mathrm{AdV}$ (range 564-3763 nuclei $/ \mathrm{mm}^{2}$, mean $221 \mathrm{l}$ (SD 644) nuclei $/ \mathrm{mm}^{2}$ ). In contrast, very high doses of AdV significantly reduced the endothelial cell count to 98 (129) nuclei $/ \mathrm{mm}^{2}$. Since these corneas received high volumes of AdV stocks ( $40 \mu \mathrm{l}$ in a total $300 \mu \mathrm{l}$ transduction volume) it was considered that the AdV vehicle itself ( $10 \%$ glycerol in PBS), rather than the AdV particles, may have damaged corneal endothelium. However, three corneas in the high dosage group received greater volumes of $\mathrm{AdV}$ stock (50-100 $\mu \mathrm{l}$ in a total $300 \mu \mathrm{l}$ transduction volume) and did not have reduced endothelial cell densities (2383 (222) nuclei $/ \mathrm{mm}^{2}$ ).

To examine transgenic protein production, five corneas were transduced with high doses of $\operatorname{AdV}\left(6 \times 10^{7}-3 \times 10^{8} \mathrm{pfu} /\right.$ cornea) encoding secreted ScFv protein and production was monitored in vitro. Supernatants were sampled regularly and assayed by flow cytometry (fig 2). Protein production peaked at 2 weeks post-transduction at 2.4 (SD 0.9) $\mu \mathrm{g}$ per cornea per day, and declined to $1.2(0.4) \mu \mathrm{g}$ per cornea per day by day 33. After 33 days in organ culture following transduction, corneas contained enlarged endothelial cells and had reduced endothelial cell densities (431 (685) nuclei/ $\mathrm{mm}^{2}$ ) but $64 \%$ (22\%) of cells still expressed eGFP.

\section{DISCUSSION}

Human corneas have previously been shown to be transduced efficiently by recombinant adenoviral vectors. ${ }^{9}{ }^{15}$ In this study, human corneas were efficiently transduced by AdV following up to 28 days cold storage and transgene expression in vitro was maintained for at least 1 month. The efficiency with which endothelium was transduced varied but did not depend on endothelial cell density, suggesting that factors other than multiplicity of infection are important. High doses of between $5 \times 10^{7}$ pfu and $3 \times 10^{8}$ pfu AdV per cornea resulted in transgene expression in $12-100 \%$ of corneal endothelial cells, with no decline in cell density relative to corneas receiving no or low $\left(2 \times 10^{6} \mathrm{pfu} / \mathrm{cornea}\right)$ doses of AdV. Very high doses of AdV (MOI: 10 000) reduced corneal endothelial cell density, probably as a result of viral toxicity. Transgenic protein production peaked at 2 weeks post-transduction at $1.4-3.3 \mu \mathrm{g}$ per cornea per day. The decrease in production rate after 2 weeks probably resulted from a loss in endothelial cell number during extended organ culture. Long term transgene expression in vitro does not necessarily translate into prolonged expression in vivo, ${ }^{16}$ although reporter gene expression has been observed for up to 12 weeks in syngeneic murine corneal grafts transduced ex vivo with $\mathrm{AdV} .{ }^{17}$ In the context of using a gene therapy approach to modulate corneal graft rejection, indefinite transgene expression may not be required.

Benefits of replication defective adenoviral vectors are that they are relatively easy and comparatively safe for laboratory workers to handle, can be grown to high titre, and can accommodate large transgenes. ${ }^{18}$ The problems associated with adenoviral vectors are threefold. Firstly, they are immunogenic. ${ }^{19}$ Secondly, they have been associated with at least one death after systemic administration to a human patient. ${ }^{20}$ Thirdly, they are non-integrative and do not therefore produce longlasting effects, especially in cells with high mitotic potential. ${ }^{21}$ Vector immunogenicity is not an insurmountable problem: the newer adenoviral vectors are very weakly or non-immunogenic, ${ }^{22}$ and even first generation adenoviral vectors can be administered repeatedly to the anterior segment of the eye without serious sequelae. ${ }^{23}$ Systemic administration of the very large numbers of adenovirus vector particles ${ }^{20}$ that appear to be required to correct systemically acting gene defects may not be necessary for genetic modification of the cornea, assuming that a therapeutic effect can be achieved by ex vivo treatment of the donor cornea before surgery. Finally, relatively short term expression of transgenes within the eye may be sufficient to modulate an allograft response in the longer term. ${ }^{3}$ The loss or silencing of episomal elements may actually improve vector safety, given that there is no risk of the insertional mutagenesis that has bedevilled recent clinical trials using integrative vectors. ${ }^{24}$

\section{ACKNOWLEDGEMENTS}

We thank Mrs M Philpott and Mrs B McGrath in the Eye Bank of South Australia, and the families of some eye donors for the provision of human corneas considered to be unsatisfactory for clinical transplantation for this research study.

\section{Authors' affiliations \\ C F Jessup, H M Brereton, D J Coster, K A Williams, Department of Ophthalmology, Flinders University, Adelaide, Australia}

Funding: This study was supported by the National Health and Medical Research Council of Australia and the Ophthalmic Research Institute of Australia. CFJ is supported by the South Australian Joyner scholarship in Medicine. The funding bodies had no direct input into study design, collection, analysis or interpretation of data for this publication.

Competing interests: none declared.

Ethics approval: Necessary ethics committee approval was secured for the study from the Flinders Clinical Research Ethics Committee.

Correspondence to: Dr Keryn Williams, Department of Ophthalmology, Flinders Medical Centre, Bedford Park, South Australia 5042, Australia; keryn.williams@flinders.edu.au

Accepted for publication 1 January 2005

\section{REFERENCES}

1 Williams KA, Muehlberg SM, Lewis RF, et al. How successful is corneal transplantation? A report from the Australian Corneal Graft Register. Eye 1995;9:219-27.

2 Pleyer U, Bertelmann E, Rieck $P$, et al. Survival of corneal allografts following adenovirus-mediated gene transfer of interleukin-4. Graefes Arch Clin Exp Ophthalmol 2000;238:531-6.

3 Klebe S, Sykes P, Coster D, et al. Prolongation of sheep corneal allograft survival by ex vivo transfer of the gene encoding interleukin-10. Transplantation $2001 ; 71: 1214-20$

4 Comer RM, King WJ, Ardjomand N, et al. Effect of administration of CTLA4-lg as protein or cDNA on corneal allograft survival. Invest Ophthalmol Vis Sci 2002;43:1095-103.

5 Muller A, Zhang EP, Schroff $M$, et al. Influence of ballistic gene transfer on antigen-presenting cells in murine corneas. Graefes Arch Clin Exp Ophthalmol 2002;240:851-9.

6 George AJ, Arancibia-Carcamo CV, Awad HM, et al. Gene delivery to the corneal endothelium. Am J Respir Crit Care Med 2000;162:S194-200.

7 Williams KA, Jessup CF, Coster DJ. Gene therapy approaches to prolonging corneal allograft survival. Expert Opin Biol Ther 2004;4:1059-71.

8 Pleyer U, Ritter T. Gene therapy in immune-mediated diseases of the eye. Prog Retin Eye Res 2003;22:277-93.

9 Oral HB, Larkin DF, Fehervari Z, et al. Ex vivo adenovirus-mediated gene transfer and immunomodulatory protein production in human cornea. Gene Ther 1997; 4:639-47.

10 Loewen N, Fautsch MP, Peretz M, et al. Genetic modification of human trabecular meshwork with lentiviral vectors. Hum Gene Ther 2001;12:2109-19.

11 Hudde T, Rayner SA, Comer RM, et al. Activated polyamidoamine dendrimers, a non-viral vector for gene transfer to the corneal endothelium. Gene Ther 1999;6:939-43.

12 Shewring L, Collins L, Lightman SL, et al. A nonviral vector system for efficient gene transfer to corneal endothelial cells via membrane integrins. Transplantation 1997;64:763-9.

13 Thiel MA, Coster DJ, Standfield SD, et al. Penetration of engineered antibody fragments into the eye. Clin Exp Immunol 2002;128:67-74.

14 He TC, Zhou S, da Costa LT, et al. A simplified system for generating recombinant adenoviruses. Proc Natl Acad Sci USA 1998;95:2509-14.

15 Bertelmann E, Ritter T, Vogt K, et al. Efficiency of cytokine gene transfer in corneal endothelial cells and organ-cultured corneas mediated by liposomal vehicles and recombinant adenovirus. Ophthalmic Res 2003;35:117-24.

16 Larkin DF, Oral HB, Ring CJ, et al. Adenovirus-mediated gene delivery to the corneal endothelium. Transplantation 1996;61:363-70. 
17 Qian $Y$, Leong FL, Kazlauskas A, et al. Ex vivo adenovirus-mediated gene transfer to corneal graft endothelial cells in mice. Invest Ophthalmol Vis Sci 2004; 45:2187-93

18 Crystal RG. The gene as the drug. Nat Med 1995;1:15-7.

19 Bennett J. Immune response following intraocular delivery of recombinant viral vectors. Gene Ther 2003;10:977-82.

20 Somia N, Verma IM. Gene therapy: trials and tribulations. Nat Rev Genet 2000;1:91-9.

21 Thomas CE, Ehrhardt A, Kay MA. Progress and problems with the use of viral vectors for gene therapy. Nat Rev Genet 2003;4:346-58.
22 O'Neal WK, Zhou H, Morral N, et al. Toxicity associated with repeated administration of first-generation adenovirus vectors does not occur with a helper-dependent vector. Mol Med 2000;6:179-95

23 Borras T, Tamm ER, Zigler JS Jr. Ocular adenovirus gene transfer varies in efficiency and inflammatory response. Invest Ophthalmol Vis Sci 1996;37:1282-93

24 Hacein-Bey-Abina S, von Kalle C, Schmidt M, et al. A serious adverse event after successful gene therapy for X-linked severe combined immunodeficiency. N Engl J Med 2003;348:255-6.

\section{Clinical Evidence-Call for contributors}

Clinical Evidence is a regularly updated evidence-based journal available worldwide both as a paper version and on the internet. Clinical Evidence needs to recruit a number of new contributors. Contributors are healthcare professionals or epidemiologists with experience in evidence-based medicine and the ability to write in a concise and structured way.

Areas for which we are currently seeking authors:

- Child health: nocturnal enuresis

- Eye disorders: bacterial conjunctivitis

- Male health: prostate cancer (metastatic)

- Women's health: pre-menstrual syndrome; pyelonephritis in non-pregnant women

However, we are always looking for others, so do not let this list discourage you.

Being a contributor involves:

- Selecting from a validated, screened search (performed by in-house Information Specialists) epidemiologically sound studies for inclusion.

- Documenting your decisions about which studies to include on an inclusion and exclusion form, which we keep on file.

- Writing the text to a highly structured template (about 1500-3000 words), using evidence from the final studies chosen, within 8-10 weeks of receiving the literature search.

- Working with Clinical Evidence editors to ensure that the final text meets epidemiological and style standards.

- Updating the text every six months using any new, sound evidence that becomes available. The Clinical Evidence in-house team will conduct the searches for contributors; your task is simply to filter out high quality studies and incorporate them in the existing text.

- To expand the topic to include a new question about once every 12-18 months.

If you would like to become a contributor for Clinical Evidence or require more information about what this involves please send your contact details and a copy of your CV, clearly stating the clinical area you are interested in, to Klara Brunnhuber (kbrunnhuber@ bmigroup.com).

\section{Call for peer reviewers}

Clinical Evidence also needs to recruit a number of new peer reviewers specifically with an interest in the clinical areas stated above, and also others related to general practice. Peer reviewers are healthcare professionals or epidemiologists with experience in evidence-based medicine. As a peer reviewer you would be asked for your views on the clinical relevance, validity, and accessibility of specific topics within the journal, and their usefulness to the intended audience (international generalists and healthcare professionals, possibly with limited statistical knowledge). Topics are usually 1500-3000 words in length and we would ask you to review between 2-5 topics per year. The peer review process takes place throughout the year, and our turnaround time for each review is ideally 10-14 days.

If you are interested in becoming a peer reviewer for Clinical Evidence, please complete the peer review questionnaire at www.clinicalevidence.com or contact Klara Brunnhuber (kbrunnhuber@bmigroup.com). 